\title{
Ezagutzaren dinamika Ikas Komunitateetan
}

\author{
David Pastor Andrés \\ Didaktika eta Eskola Antolakuntza \\ Bilboko Irakasleen Unibertsitate Eskola \\ Euskal Herriko Unibertsitatea (UPV/EHU) \\ Justo Bereziartua Zendoia \\ Didaktika eta Eskola Antolakuntza \\ Donostiako Irakasleen Unibertsitate Eskola \\ Euskal Herriko Unibertsitatea (UPV/EHU)
}

DOI: $10.1387 /$ tantak.15555

GAKO-HITZAK: Ikas Komunitateak, praktika-komunitateak, ikaskuntza kooperatiboa, ezagutzaren eraldaketa, Lehen Hezkuntza.

\section{SARRERA}

Laurogeita hamarreko hamarkadan, Eusko Jaurlaritzako Berriztapen Pedagogikoaren Zuzendaritzak eta Bartzelonako Unibertsitateko CREA (Gizarte eta Heziketarako Ikerkuntza Zentroa) ikerkuntza-taldeak Ikas Komunitateen proiektua jarri zuten martxan, elkarlanean, Euskal Autonomia Erkidegoko lau zentrotan. Zentro horiek hezkuntza-proiektu berri bat abiatzeko bidea ematen dute; izan ere, porrot akademiko handia izatearren hautatu dira, ikasle-taldeen aniztasunaren egoerari heltzeko arazo ugari dituztelako edota dauden lekuetan gizarte-bazterkeriarekin loturiko arazo anitz daudelako. Aldi berean, proiektuak eraldaketa proposatzen du, bai eskolarena, baita inguruarena ere, eta, horretarako, eskolako partaide guztiak hartzen ditu kontuan. Emaitza onak ikusi ostean, eta, hezkuntza-berriztapenaren alorrean lehentasuna izanik, ekimena zabaltzen hasi zen hastapeneko zentroez bestelako ezaugarri sozioedukatiboak dituzten eskoletara ere. Esperientzia berritzaile horiek aurrera eramateko gogo handiz agertu ziren, baita ere, «praktika on»en paradigma ez zirenak, eta, emaitzei begiratzen badiegu, dirudienez, etekin onak lortzen ari dira zentroetan. Ikas Komunitateen proiektuak berekin daraman gaitasun eraldatzaileak egokitzeko berezko ahala erakusten du. Egokitzapen horretan, eskolaren -inguruarekin batera - eta proiektuaren arteko sinbiosia lortzen da, hezkuntzako arrakastaekintzak sustatuz. 
2005. urtean, Eusko Jaurlaritzako Hezkuntza, Unibertsitate eta Ikerketa Sailak, artikulu bat argitaratu zuen Euskal Administrazioak Ikas Komunitateetan duen zereginari buruz (Mugertza, 2005). Egileak adierazten duenez, hamar urte igaro eta gero, proiektuak hezkuntza- eta gizarte-beharrei erantzuna ematen jarraitzen du oraindik. Gizartean ageri diren erronken aurrean, ikasleak prestatzea da asmoa: informazioaren eta komunikazioaren teknologiak eskuratu eta horretan trebatzea, genero-gaiak eta kulturartekotasuna hedatzea, ingurumena, garapen sozioekonomikoa eta etengabeko prestakuntzaren beharraz jabetzea. Beraz, hezkuntzaren lehentasunen artean, ezagutza instrumentalez gainera, beste ikas-ildo batzuk indartzen dira, balioen eta jarreren ikaskuntza sustatzen dutenak, hala nola hausnarketa, elkartasuna, autonomia eta ikasten ikastea. Hori guztia gauzatu ahal izateko, ezinbestekoa da hezkuntza-komunitate osoaren parte-hartzea. Hogei urte igaro eta gero, indarrean diraute beharrizan horiek Euskal Autonomia Erkidegoan.

Bitartean, Europako Batzordearen hainbat txostenetan, heziketa-praktika arrakastatsu legez onartu da Ikas Komunitateen eredua (Padrós, Duque eta Molina, 2011), hots, kalitatezko heziketa eskaintzen die ikasle guztiei, eta, aldi berean, eskolako porrota eta absentismoa ekiditen dituen praktika bat da.

Gaur egun, ikus daiteke edozein hezkuntza-erakundetan onargarriak diren helburu eta dinamiken ekimen bat dela Ikas Komunitateena, erakundearen ezaugarriak era batekoak edo bestekoak izan. Osatze- edo indartzeizaerako proposamena izatetik - era globalean ulertuta -, neurri horretako proiektu batek izan ditzakeen helburu eta irismenen irudi integralago batera pasatu zen.

Artikulu honen helburua Ikas Komunitateetan ezagutzaren dinamika zertan datzan deskribatzea da; horretarako, komunitate horietako gertakarien eta eguneroko jardueren analisia egingo da. Hezkuntza-proiektuaren eraikuntza- eta bilakaera-prozesuak interpretatu nahi dira, ikasten duten erakundeen praktika-komunitateen paradigmatik abiatuz.

\section{KOMUNITATE-KULTURA HEZKUNTZAN}

Ikas Komunitate izatera iristeko eraldaketa-prozesua ez da samurra. Askotan, egunerokoan sortzen diren egoera zehatzei edo puntualei ematen zaien konponbidea besterik ez dakarte aldaketa-ekimenek; bestetan, aldi bateko saio edo esperimentuak izan ohi dira, jarraipenik ez dutenak. Ikas Komunitateetan, ikastetxea bere osotasunean hartuta eta benetako etorkizunari begira garatzen dira esperientziak. Duquek, Mellok eta Gabassak (2009) adierazten dutenez, halako komunitateak ez dira ez metodologia berritzailea ez adabakiak aplikatze soila; hori baino harago doaz. 
Ikastetxearen eraldaketaren aldia ideia oinarrizko eta logiko batekin lotuta dago: komunitate osoaren parte-hartze aktiboa eta demokratikoa (Ferrer, 2005). Hausnarketa-prozesuak - sensibilizazio- eta erabakitzefasea - Ikas Komunitateko eragile guztien inplikazioarekin eramaten dira aurrera, hasieratik. Ikasleen, irakasleen, teknikari eta bestelako profesionalen, eta bereziki familien parte-hartzea eskatzen du. Aldi berean, lekua ematen zaio inguruko eragileen, elkarteen edo instituzioen ekarpenari. Era horretara, ez fisikoa baina erreala den langa bat apurtzen da: eskola bere gertuko errealitatetik isolatzen duen erakunde gisa indartzen du langa horrek.

Ikas Komunitatean gauzatzen den aldaketa metodologikoa eta antolakuntzarena geletan agertzen dira, eta, gehienetan, emaitzen hobekuntza dakarte. Emaitzen hobekuntzak ez dira ikasketa instrumentaletan bakarrik adierazten, baizik eta hainbat alderdi garrantzitsutan ere aurkitu ditzakegu: irakasleen eta komunitatea sortzen duten gainerako agenteen arteko elkarbizitzan, adibidez. Ageriko emaitzak dituzten praktikei buruzko ikerketa zientifikotik jasotzen dira ebidentziak, lehenik, eta, gero, haietatik abiaturiko ereduak aplikatzeko ahalegina egiten da (Padrós et al., 2011); ikasle guztientzat kalitatezko hezkuntza eskaintzen duten ereduak, alegia. Eskolaporrotari edo -uzteari aurrea hartzeko arrakasta duen neurrietako bat hau da: ikasleak ez banatzea errendimenduaren edo ahalen arabera bereizten diren hezkuntza-ibilbidetan. Egokiena ikasle guztiei ikaskuntza-egitarau bera eskaintzea da, eta, aldi berean, prestakuntza-bideak malguak izatea, guztiei goi-mailako hezkuntzara iristea errazteko. Hezkuntzari ekitatea dakarkioten praktika gisa, ikasteko denbora gehitzea, familien laguntza eta halako ekimen eraginkorrekin batera, ontzat ematen dira, baita ere, taldekatze mistoak eta talde heterogeneoak.

Ikas Komunitate bihurtzeko erabakia hartzen duen ikastetxe orok bere egitura - erlazionatzeko eta kudeatzeko estiloak - eta ikasketa-ereduak moldatzea dakarren gizarte- eta kultura-eraldaketa bat eramaten du aurrera. Erakundea era horizontal batean lan egiten hasten da, eta bilgune horretan agertzen diren elkarrizketa eta ekintza bateratuak hezkuntza-esanahien eraikitzaile bilakatzen dira.

\section{ESPERIENTZIA DIALOGIKOA ETA IKAS KOMUNITATEAK}

Ikaskuntza dialogikoa gizarte-zientzien komunikazio-izaeran oinarritzen da. Planteamendu horretan, gizarte-errealitatea pertsonen arteko interakzioan eraikitzen dela azaltzen zaigu. Ikas Komunitateen hezkuntza-helburuetako bat egoera hobezinak sortzea da, interakzio-prozesuen bitartez elkarrizketa abia dadin (Jaussi, 2003).

Ikasketa dialogikoaz mintzatzea berdinen arteko elkarrizketaz, adimen kulturalaz, eraldaketaz, ezagutza instrumentalaz, zentzua sortzeaz, 
elkartasunaz eta desberdinen arteko berdintasunaz mintzatzea da (Jaussi, 2003; Flecha eta Larena, 2008; Duque et al., 2009). Ikaskuntza eta hura lortzeko motibazioak aktibatu eta bizkortu ditzaketen interakzioak gertarazten dituzten aldaketei ematen dio garrantzia ikasketa dialogikoak. Aldi berean, ezagutza zientifikoak, metodologiak eta esanahien eraikuntzaprozesuak ere hartzen ditu kontuan. Ikuspegi horretan, ezinbestekoa da umeekin lan egiten duten pertsona guztien formazioa.

Atzean inor lagatzen ez duen eredu bat sortu nahi da; entzuteko eta parte hartzeko lekua ematen zaie komunitateko ahots guztiei, ikaskuntzaren kalitatea galdu gabe. Zentroan, elkartzeko eta komunikatzeko espazioak indartu egiten dira, benetako inklusibitatea lortzeko asmoz. Inklusibitatea bere esanahi zabalenean ulertzen da, eta eskolako espazio guztiak, definizioz, ikasketarako espazio bihurtzen dira (Elboj, Puigdellívol, Soler eta Valls, 2002). Inklusibitatea lortzeko, ezinbestekoa da familien eta eskolaren arteko lankidetza bultzatzea, denentzako espazioak sortzea, eta, horretarako, ezinbestekoak dira enpatia, komunikazioa eta elkar aintzat hartzea (Aguado, 2010). Guneak mugatu gabe, hezteko eta irakasteko prestatzen da eskola; ikasleek beren artean ikasten dute, eta irakasleek eduki akademikoak antolatzen dituzte. Gelak irekita daude, eta gainerako pertsonei aukera ematen zaie irakaskuntza- eta ikaskuntza-prozesuetan parte har dezaten (Ferrer, 2005). Gela barruan, boluntarioek eta familiek esku hartzea sustatzen da Ikas Komunitateetan. Boluntarioaren irudia ez da parte-hartzaile gazte baten irudira soilik mugatzen; edozein motatako prestakuntza izan dezaketen pertsonez hitz egiten ari gara. Pertsona horiek, laguntzeko prest egonik, proiektuarekin bat egiten duten lankideak dira. Ikasle ohiek, irakasle-ikasketetako ikasleek, amamek eta aititek momentuak partekatzen dituzte umeekin (Jaussi, 2008; Ziluaga eta Iturbe, 2011). Beren jakintzatik eta iaiotasunetatik - hots, adimen kulturaletik - abiatuz, ikas-saioak dinamizatzen dituzte, irakasleekin batera.

Ikasteko erakundeak izanik, Ikas Komunitateen berariazko ezaugarritzat hartzen dira honako hauek: bizitza osoko ikaskuntza kolektiboaren kultura, garapen profesionalarekiko engaiamendua, ikasleek emaitzak hobetzeko duten ardura, gogo bizia, inklusioaz jabetzeko era bat, irekitasuna eta ikuskera bakar baten eraikuntza (Voulalas eta Sharpe, 2005). Ikertzaile horiek beren ikerketa-lanean jasotzen dutenez, eraldaketa-prozesuek beharrezkoa dute korporazio-ikasketaren kultura garatzea. Eraldaketa horietan, kritikak balio handia du, eta laguntza gisa hartzen da. Kultura-ikuspegi horretan, konfiantzak eta elkarlanak aurrera egiten dute, eta badago oker egoteko aukera ere. Ikasteko, egokitzeko eta inguruarekin interakzioan haziz joateko gaitasunak nabarmentzen dira erakunde osoan. Hori guztia, etengabeko prestakuntza-dinamika batzuen barruan, akatsetatik eta gizarte aldakorrak sortzen duen sakaduratik ikasiz. 


\section{ANTOLAKUNTZA-EGITURAK IKAS KOMUNITATEETAN}

Antolakuntza-eredua eta ikasketak indartzeko jarduerak dira Ikas Komunitateen ardatz bereizgarriak, eta proiektua bere planteamendu didaktikoarekin ulertzeko oinarrizko printzipioak. Erakundeak horizontaltasuna sustatzen du, eta erakundean indartzen dira elkartzeko eta kontsentsura ailegatzeko garapen komunikatiboak. Pertsonak, proposamenak eta ideiak estatus hierarkikoagatik baino gehiago argumentuetatik balioesten direla ohartzean, esperientzia komunikatiboak berak parte hartzea eragiten du.

Neurri handi batean, kudeaketa batzorde mistoek eramaten dute aurrera, beste organo kolegiatu ohikoagoak alboratuz; eskolako kontseilua, kasurako (Barrio de la Fuente, 2005). Parte-hartze zuzenaren bidez, aldaketarako eta hobetzeko proposamen berriak aurkezten eta eztabaidatzen dituzte, eta, aldi berean, proiektuen kudeaketaz arduratzen dira. Batzorde mistoek beharrizanei erantzuten diete, eta batzorde kudeatzailea arduratzen da haien funtzionamenduaz eta dinamizazioaz. Batzorde horietan, ikasle, irakasle eta familien arteko oreka bilatzen da, eta irekita daude eskolarekin harremana duten beste eragile, erakunde edo instituzioentzat ere. Ikastetxearen egunerokotasunean sortzen diren arazo edo egoeretan esku hartzen dute, bai erantzun azkarra behar duten eginkizunetan, bai epe luzera begira aurrera eramaten dituzten proiektuetan. Bestalde, eskolako asanblea arduratzen da batzordeek aurkeztutako proposamenak eztabaidatu eta, behar izanez gero, onespena emateaz; Ikas Komunitateko pertsona orok osatua da asanblea hori. Halere, Ikas Komunitate guztietako eredu organikoa ez da berdina, eta, kasuz kasu, errealitatearen beharretara eta aukeretara hobeto egokitzen den eredua aurkitu daiteke.

Talde elkarreragileen bitartez gauzatzen den ikaskuntzak berebiziko garrantzia du heziketa-prozesuan. Proposamen pedagogiko horrek, alde batetik, umeen ikasketa sustatzen du, eta, bestetik, irakaslearen eta haren ikasleen leku itxi bat izateari uzten dio gelak. Barrio de la Fuentek (2005) adierazten duen bezala, talde elkarreragileak gelaren antolaketa malguak dira, jakintza eta esperientzia anitzen bilgune izanik elkarren arteko ikasketa indartzen dutenak. Era horretara, partaide bakoitzarentzat eraginkorra izango den eraikuntza kolektiborantz eginez, espazio eta denbora hori eraldatzeko beharrezkoak diren trebetasun sozialak garatzen dira.

Gela taldeka antolatzen da, eta ikasle gutxiko taldeak osatzen dira. Haietako bakoitzari heldu batek laguntzen dio, boluntario izan nahiz irakasle izan. Dinamika horrek berekin dakar saioak irauten duen bitartean talde bakoitzak heldu batekin lan egitea hainbat eratako edukien inguruan. Aldiro, heldua taldez aldatu ohi da, eta beste ikasketa-proposamen bat helarazten dio talde berriari. Arreta eta motibazioa mantentzeko, ezinbestekoa da denboraren kontrola (Elboj et al., 2002). Hala, jakintza sortzeko eta transmititzeko moduak sortzen dira, eta, ondorioz, esperientzia kooperatiboa, solidarioa eta inklusiboagoa bideratzen dira. Ikaskun- 
tza kooperatiboak, bere helburua lortzeko, talde osoaren beharra eta inplikazioa eskatzen du. Taldeak bereganatu behar du xedea, zailtasunak dituzten ikasleak albo batera gelditzearen arazoa saihestuz. Taldeko bakoitzak irakaslearen papera hartzen du bere kideen ezagutzaren eraikuntza-prozesuan laguntzean. Ikasketa-jarduera horren ekarpena esanguratsua da oso, ezagutza kontzeptualetik harago baitoa lortzen den emaitza. Gainera, irakaslearen ikuspuntua ere eraldatu egiten da, komunikazioak elkarrekin lan egiteko duen garrantziaz ikasten baitu. Azkenik, boluntarioen parte-hartzeak aberastu egiten du eskola komunitate-espazio ireki bat balitz bezala ulertzeko modua. Horrekin batera, partaide guztien arteko elkarrizketa sustatzen du, eta inguruarekiko harreman-sare berri bati loturiko jakintza eraikitzen da.

Batzorde mistoak zein talde elkarreragileak ikastetxea ikusteko eta ulertzeko eta bertan partaide sentitzeko era berriak sortzeko antolakuntzaegiturak dira. Bide batez, ezagutza anitz eraikitzeko guneak ere badira egitura horiek.

Ikusten denez, lankidetza eta parte-hartzea ez dira bideratzen ohiko eskola-organoetatik soilik. Ikastetxe gehienetan, familien elkarteek ikasle, guraso eta tutoreen interesak defendatzen dituzte, eta funtzionamenduan parte hartzen dute; baina haien antolaketa-esparrua murritza da: eskolaz kanpoko jardueran, hezkuntza-zerbitzuetan (jantokia, eskolako garraioa, zaintza eta oporretako zerbitzuak) eta familientzako aktibitateetan zentratzen da (Santiago, Lukas, Arrieta et al. 2012). Ikas Komunitatetan, familien elkarteekin lan egiten da, baina hori ez da bide bakarra eskolarekiko inplikazioa lortzeko. Horregatik, aparteko garrantzia ematen zaie batzorde mistoei eta talde elkarreragileei, egundoko aukera ematen baitute, alde batetik, heziketa-prozesuak eta haien kudeaketa hobetzeko, eta, baita ere, parte-hartze zuzena sustatzeko. Familiak eta boluntarioak modu aktiboagoan hartzen dira kontuan, eta aukera gehiago aurkitzen dituzte proiektuarekin bat egiteko. Eskola espazio demokratiko bihurtzea errazten $\mathrm{du}$, pertsonei lekua eginez eta hitza emanez.

\section{PRAKTIKA-KOMUNITATEEN IKASKUNTZA-EREDUA}

Oro har, erakunde bateko zenbait pertsonak elkarrekin lan eginez sortzen duten antolakuntza-elkarte informala da. Pertsona horiek gauzak egiteko era, hitz egiteko modu, sinesmen eta balioak, hau da, praktikak, konpartitzen dituzte, lantalde batean (Hong eta Kuo, 1999; Tomassini, 2000). Praktika-komunitateetan, jardunean diren lankideen balio-sistema berregin daiteke, ezagutza praktikoa erlazio-sistema bezala (Barragán, 2015).

Zentzu horretan, pertsonen arteko konpromisoan sortzen eta hedatzen da ikaskuntza; ez, ordea, norbanakoaren ekintza isolatuan. Vigotskyk (1978) dioenez, ikaskuntza gertaera sozial bat da; gizakiak taldeko partai- 
deekin dituen harremanen bidez ikasten du, kultura kolektiboak bereak dituen gogamen-eredu eta -esanahiak ulertu eta barneratuz.

Ikuspegi horretatik, ezagueren eraldaketan oinarritzen diren ekintzak dira lana, ikaskuntza eta berrikuntza, erakundeak bere ezaguerak etengabe joan-etorrian erabili eta berritze-beharrei erantzuteko asmoz ezagutza berriak sortzen diren heinean (Wenger, 1998; Tomassini, 2000). Jarduera formatzaileek ezagutzaren eraldaketa berekin daramatela onartzen badugu, prestakuntza ez da soilik transferentzia-ekintzen multzo bat izango (jakintza duen pertsonak ez dakien beste bati emateko). Ikaskuntza jarduera konplexuagoa da, transferentziaren ardatza eraldaketa-prozesuak errazteko ariketetan bilatu eta ezagutzaren esanahi bat baino gehiago onartzen duena.

Praktika-komunitateen ereduak onartzen du testuinguru idiosinkratikoetan oinarritzen den esperientziaren interpretazioa dela ezagutzaren alderik esanguratsuena, kontuan izanik errealitateari zentzua emateko prozesu indibidualak errazten eta, aldi berean, mugatzen dituztela testuinguru horiek (Resnick, 1993). Pertzepzio- eta ulermen-eskema ezagunak aldatzeak ezagutzaren esanahia eraldatzea eskatzen du, irakaskuntzaren, taldeetan aritzearen eta norberari begiratzearen ondorioz (Hong eta Kuo, 1999). Ekintza kognitiboak gertatzeko une eta egoerek garrantzi handia dute. Egoera jakinei atxikitzen zaien kognizioan, pertsona sentikorra da bere inguru kulturalarekiko, pertsonaren ezagutzak egituratu eta haien eraikuntza soziala antolatzeko erreferentzia-ehun bat eskaintzen baitu inguru horrek. Gizarteratze-prozesuek ezagutzaren deskodetzaile gisa eragiten dute, eta, hala, esanahi-sareak sortuz, ezagutza haziz doa. Gogamen-eredu bateratuak agertzen dira kideen arteko harremanetan, eta erakunde-kulturaren esparruan ezarri, legitimatu eta birsortzen dira eredu horiek (Zalazar, 2011).

Praktika-komunitateak esplizitu bihurtzen du gizarte-sareen eta taldeen esan gabeko ezagutza, bere bilakaeran ezagutza gehiago eskuratzeko eta transferitzeko bidea ematen duen egitura formal bat eskainiz. Egitura bizidun eta antolatua da, funtsezko hiru osagai hauen arteko interakzio jarraituan gauzatzen duena bere jarduera: narrazioa, ideiak eta historiak sortu eta haien berri emateko eta gordetzeko baliabidea; eraikuntza soziala, bai maila sozialean, bai norbanakoarengan identitateak erabakitzeko bide gisa; eta elkarlana, kideei lekuko ezagutzaren ibili kolektiboetan parte hartzen laguntzen diena.

\section{EZAGUTZAREN BIHURTZEA PRAKTIKA-KOMUNITATEETAN}

Erakunde bateko kideek, batera jarduteagatik, barneko nahiz kanpoko ezagutzaren osagai soziopertsonalak eta kontzeptuak elkarretaratzen dituzte, eta, aldi berean, norbanakoari eta taldeari dagozkion alde anitzetan eragiten du ezagutzaren eraldaketak (Lundvall eta Johnson, 1994). Nola 
elaboratzen dira ezagutza horiek? Zerk bihurtzen ditu baliagarri erkidegoarentzat?

Enpresen eremuan, ezagutza sortzen duen enpresa deritzon teoriatik etorri da galdera horien erantzun ezagunena (Nonaka, 1994; Nonaka eta Takeuchi, 1995). Ikasten duten enpresek elkarren artean lotura duten prozesu- eta sistema-sare ikusgarriak dituzte. Sare horien barnean, erakundeari hobekuntza eta arrakasta eranstea da norbanakoaren eta taldeen arteko ikaskuntzaren dinamiken emaitza.

Ildo horretan, erakunde-ezagutza dinamikoaren sorrera esplikatzen duen teoria garatu dute Nonakak eta Takeuchik (1995). Teoria horrek ezagutzaren bihurtze-prozesua hartzen du oinarritzat: eraldaketa bidean, esan gabekoa izatetik esplizitua izatera eta norbanakoarengandik taldera iragaten da ezagutza. Nonakak (1994) dioenez, esan gabeko ezagutzaren eta esplizituaren arteko elkarrizketa jarraituaren bitartez ezagutza sortzeko mekanismo gisa ikus daiteke bihurtze-prozesua, Tseng-ek (2010) ekintzan gertatzen den ikaskuntza-prozesu gisa deskribatzen du. Erakunde osoan sortzen diren ezagutza esplizituak bereganatu, eta esan gabeko bihurtzen ditu pertsona guztiak. Bihurtzea maila indibidualean abiatzen da; gero, talde elkarreragileetan zehar iragan ahala, haziz eta garatuz joaten da. Zentzu horretan, sekzio, sail edo talde jakinetatik harago ere irits daiteke.

Ezagutzaren bihurtze-prozesuak jakintza berri bat sortzea dakar, eta, hori baino garrantzitsuago, komunikazio-egoeren baitako transferentziaezagutza bat, esan gabekoaren eta esplizituaren arteko jendarte-jardunean zehar. Nonakaren ereduak lau jarduera interaktibo aurkezten ditu: sozializazioa, azaleratzea, konbinazioa eta barneratzea.

Sozializazio-prozesua esperientziak elkarrekin bizitzea da, aurreko gogamen-ereduetan errotutako beste ezagutza batzuk sortuz (Tomassini, 2000). Prozesu horretan, bere izaera esan gabekoan jarraitzen du ezagutzak, lehendik dagoena beste ezagutza esan gabeko berri sofistikatuago batekin lotuz (Al-adaileh, Khadra, Hacini, 2012). Eragiketa hori era formalean nahiz informalean gerta daiteke. Esparru formalean, adibidez, erakusbidezko irakaskuntzan eta ikaskuntzan ikus daiteke; halakoetan, irakaslearengandik irteten du ezagutzak, zuzenean - hitzezko komunikazioan edo erakuspenean -, eta ikaslearengan txertatzen da ezagutza, esan gabeko bihurtuta. Bestalde, gerta daiteke erakundeko elkargune informaletan edo kanpoko pertsonekin izaten diren harremanetan ere. Sozializazio-eremuetan ezagutza lortzeko oinarriak hauek izaten dira: lekuko esperientziak, elkarrizketa askea eta pertsonen arteko konfiantza. Sozializazio-ekintzaren egitekoa, batez ere, agerraraztea da, norbanakoak elaboratu ahal izango dituen ezagutzak aurkeztea.

Bigarren prozesua, azaleratzea deritzona, esan gabeko ezagutzak zeregin praktikoetan erabiliko diren ideia esplizitu bihurtzea da. Eraikuntza hori, ezinbestean, taldean gertatzen da. Metaforak, analogiak, hipo- 
tesiak eta irudiak erabiltzen dira maiz, taldean hausnartuz, lankideen arteko elkarlanean ideia eta produktu berriak sortzeko asmoz. Gogamenereduak berbalizatu egiten dira, bakoitzaren ezagutza ulertzen errazago diren formetara eraldatu; ondoren, kontzeptu kolektibo esplizituagoetan mamitzen dira (Al-adaileh et al., 2012). Fernándezek eta Leidner-ek (2008) dioten bezala, ezagutzaren aldaketan, beharrezkoa da informazioa komunikatzea eta ezagutza esplizitua intsuldatzea, eta lankideen artean denek goi-mailako antzeko ezagutza bateragarria edukitzea eskatzen du horrek.

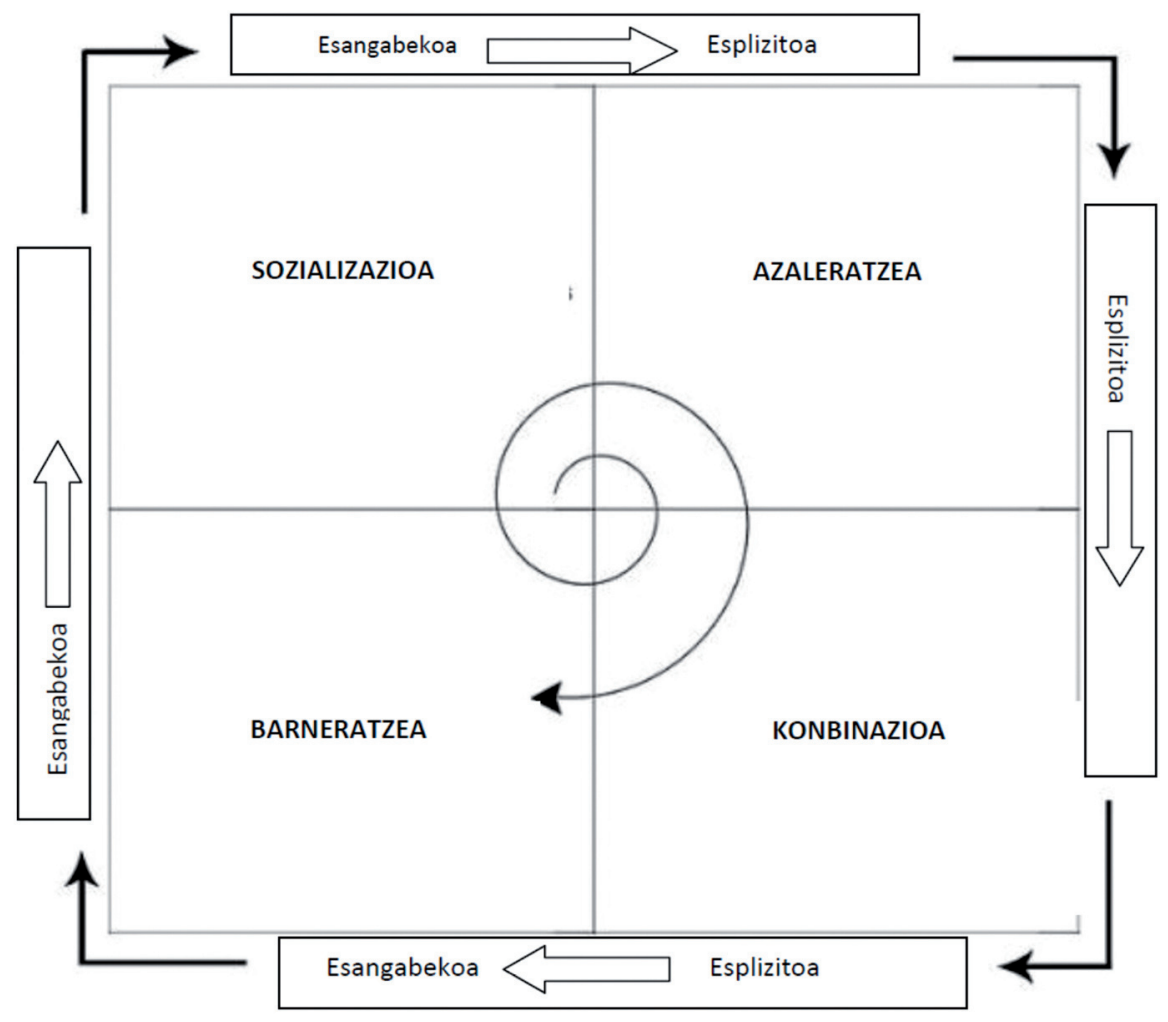

1. irudia

Ezagutzaren espirala. DeustosareLab-en matrizaren egokitzapena

Iturria: http://deustosarelab.deusto.es/wp-content/uploads/2012/09/espiral.png [2013ko irailaren 20a]

Nonakak eta besteek (2000) hala definitua, hirugarren fasean, konbinazioan, ideiak sistematizatzen dira, ezagutza esplizituko elementuak elkartuz 
eta, ondorioz, sare kognitibo konplexuagoak osatuz. Bihurtze-era horretan, lagungarri izan ohi dira era honetako eragiketak: interpretazioak, sintesiak, eta barneko eta kanpoko ezagutza zabaltzeko uneak. Eskuratu den informazioa argitu, batu, sailkatu, osatu eta ezagutza esplizituak kategorizatuz, ezagutza berriak lor daitezke (Tomassini, 2000).

Laugarren prozesua, azkena, barneratzea da, ezagutza esplizituak esan gabeko ezagutza bilakatzea. Praktika bidezko ikaskuntzari lotuta dago urrats hori erabat, pertsona bakoitzak bere jardueretan aurrera eginez lortutako esperientzien batura baita. Elaborazio eta asimilazioen bitartez lortutako ikaskuntzaren emaitza da barneratzea; batetik, norbanakoarena (Fernández eta Leidner, 2008), eta, bestetik, baita taldearena ere, esan gabeko ezagutza-maila berriak lotu eta erakundearen barnean guztientzako gogamen-ereduak sortzen baitira (Tomassini, 2000).

Nonakak ezagutzaren espirala izenez definitzen du ezagutza bihurtzearen dinamika guztia. Bere osotasunean hartuta, esan gabekoen eta esplizituen arteko eragina haziz doa, lau prozesuen arteko harremana zabaltzen eta kudeatzen den heinean. Norbanakoengan hasten den espirala gero eta harreman-erkidego zabalagoetara hedatzen da, talde mailan, erakundearen barneko mugak zeharkatuz.

\section{LANDA-LANA}

Ikasturte oso batean egin zen ikerketa-lana, bi helburu hauen harian:

1. Ikas Komunitateak deskribatu, kideen elkarguneen egoeretan batzen diren elementu eta faktoreak zein diren jakiteko.

2. Ezagutzaren dinamikaren teoriatik abiatuta bihurtze-prozesuak ikusarazi ikastetxeko praktika jakinetan.

Ikerketa egiteko, metodo kualitatibo deskriptiboa erabili da: ikastetxeetara hurbildu, eta han bertan ezagutu dira eguneroko gertakari eta zereginak. Ikertzaileek eskolako jardueretan lekuko izanik bildu da informazioa, batez ere; eta, ondoren, landa-oharrak idatziz osatu da han jasotakoa.

\section{Lagina}

Ikas Komunitate bihurtzeko prozesu osoan, zuzen-zuzenean ikastetxeekin elkarlanean dihardu Hezkuntza Saileko aholkulari tekniko batek, eta haren proposamena entzun eta gero hautatu ziren informazio-emaileak. Hautatze-irizpideen artean, lehentasunak izan dira ikastetxeetako antolakuntza-sareen aukera eta hango lankideek zer-nolako esperientzia duten Ikas Komunitateetako hezkuntza-praktiketan. 
Pedro M. Otaño ${ }^{1}$ eta Zaldupe ${ }^{2}$ Ikas Komunitateetako lantalde eta batzordeak hartu ziren laginean.

\section{Informazioa biltzeko teknikak eta tresnak}

Ikastetxeetan informazioa biltzeko, teknika eta baliabide hauek erabili dira:

- Ikertzaileen behaketa, lekuan lekukoa, ikastetxeko ikasgeletan eta beste zenbait ekitalditan egina. Informazioa landa-oharretan jaso da.

- Solasaldi gidatuak taldetan. Talde txikitan, aurretik idatzita emandako galderei buruz hausnartu eta eztabaidatzen dute partaideek. Solasaldiei eusteko eta gaian gehiago sartzeko, gertakari eta egoeren ñabardurak gogoraraztea eta informazio-emaileei zehaztapena eskatzea da ikertzaileon egitekoa. Ikertzaileak tentsioari eusten dio solasaldian zehar (González Rey, 2000)

Galde-sorta, ikertzaileek sortua, solasaldiak gidatzeko tresna gisa erabiltzen da. Guztira, 49 item ditu: galdera irekiak, esaldi osatugabeak eta ezagutzaren lau bihurtze-prozesuei buruz estimazioeskala modura aurkeztutako galderak. Hord-ek (1996) profesionalen ikaskuntza-komunitateen diagnosia eta ebaluazioa egiteko sortutako galde-sortaren lau ataletatik hartu dira galderen gaiak (School Professional Staff as Learning Community Questionnaire): taldean konpartitzen diren ikuskerak eta balioak, ikaskuntza kolektiboa eta haren aplikazioa, besteenganako praktika pertsonala, eta elkarri laguntza emateko baldintzak (harremanak eta egiturak). Esperientziei, jarduerei, jokabideei, ezagutzei, helburuei edota gertakari kritikoei buruzko adierazpenak eskatzen dira. Galde-sortaren orrietan bertan eta solasaldian jasotako landa-oharretan erregistratzen da informazioa.

${ }^{1}$ Pedro M. Otaño Ikas Komunitatea. Zizurkilgo (Gipuzkoan) Haur Hezkuntzako eta Lehen Hezkuntza ikastetxe publikoa da. Komunitate-proiektuari 2003/04 ikasturtean eman zitzaion hasiera. Ikastetxearen Hezkuntza Proiektuaren definizioan, komunitate osoak parte hartu zuen. Batzorde mistoak proiektuaren oinarrietako bat dira. Erabakigune horietan, talde elkarreragileak, tertuliak, familien eta irakasleen formazioa, mediateka tutorizatua, eta abar, kudeatzen dira.

2 Zaldupe Ikas Komunitatea Ondarroako (Bizkaian) Haur Hezkuntzako eta Lehen Hezkuntzako ikastetxe publikoa da. 2004/05 ikasturtean, hasiera eman zitzaion komunitateproiektuari, eta huraxe dugu egun - eta geroari begira ere bai - proiektu ororen ildo nagusia. Jarduera anitz garatzen dira: ikaskuntza-irakaskuntzako talde elkarreragileak maila guztietan, liburutegia eta informatika-gela eskola-ordutegiaren ondoren, ikus-entzunezko eta eskulanetarako tailerrak, familien eta irakasleen arteko zuzendaritza-batzorde mistoak, eta familien eta irakasleen formazioa, beste batzuen artean. 
Oro har, teknika eta tresna hauek txertatu ziren elkargune komunikatibo hauetan:

- Hizkuntzen arloko irakaskuntza- eta ikaskuntza-talde interaktiboen saio bat, Lehen Hezkuntzako bosgarren mailako ikasleena, bi irakasle eta borondatezko langile batekin batera.

Ikertzaileek taldeko kideen arteko harremanari eta eraginari behatzen diote. Halaber, ikastetxearen ezaugarriei edo garrantzizkoak iruditzen zaizkien gertaerei buruz idazteko eskatzen die ikasleei.

Saioan, landa-oharrak ere hartzen dira.

- Irakaskuntza- eta ikaskuntza-praktikak, jolas modura antolatuak. Lehen Hezkuntzako ikasle guztiak aritzen dira, bost edo sei laguneko taldeak eginez. Talde bakoitzean, maila bateko baino gehiagotako ikasleak elkartzen dira, gurasoak edo familietako boluntarioak laguntzaile dituztela. Praktikak bi ordu irauten du, eta honetan datza: janari bat prestatu, prozesua idatzita ipini eta, azkenean, denen aurrean aurkeztu.

Kanpoko ikertzaileek gonbidatu gisa hartzen dute parte ekitaldi osoan.

- Bizikidetza-batzordearen bilera. Mailaz maila, lau urtetik hasi eta hamabi urte arteko ikasleen ordezkariak, zuzendaritza-taldekoak eta jantoki-zerbitzuko irakasle arduraduna biltzen dira. Saio honetan, ikastetxeko eguneroko bizitzan gertatzen diren gorabehera eta jokabide aipagarrienei buruz hitz egiten da.

Kanpoko ikertzaileak entzule dira, eta oharrak hartzen dituzte, solasaldian sartu gabe.

- Irakasle-taldearen prestakuntza-saioak. Saio hauetan, irakasleez gainera, bere borondatez ikastetxean laguntzen ari den herriko andre batek eta eskualdeko Berritzeguneko ordezkariak ere parte hartzen dute. Hiru-lau laguneko taldetan banatuta, ikastetxeko komunikaziosare eta esperientziak aztertzen dituzte, eztabaidan, bi ordutan.

Galde-sorta erabiltzen da gida moduan. Ikertzaileen zeregina, galde-sortako gaiak argitzearekin batera, taldeetan eztabaida sortu eta suspertzea da.

- Kudeaketa-batzordearen bilera. Familien ordezkariak, irakasleenak, zuzendaria eta eskualdeko Berritzeguneko aholkularia elkartzen dira. Saio honetan, batzordeak, hiru-lau laguneko taldetan jarrita, Ikas Komunitateko ekintza kooperatiboak aztertzen ditu, emandako galde-sortatik abiatuz. Solaskideek idatzita jasotzen dituzte beren adierazpenak.

Kanpoko ikertzaileak galderak argitzen, iritziak entzuten eta, tarteka, elkarrizketan parte hartzen aritzen dira, taldez talde. 


\section{Analisiak}

Metodo kualitatiboaren barruan, kasuen azterketaren bidez egin da ikerketa, ikuspegi deskriptibo batetik abiatuta. Hezkuntza-erakunde konkretuetan informazioa biltzen joan ahala, irizpide tematikoen inguruan adierazpen esanguratsuak hautemanez eta haiekin multzoak osatuz abiatu zen analisiprozesua. Grafiko honetan agertzen den bezala (2. irudia), hiru gai-eremu orokorretan banatuz multzokatu da informazioa: a) komunikazio-sareak, b) ikaskuntza-edukiak komunikazio-esperientzietan, eta c) ezagutzaren mugimenduak eta haien dinamika egoera indibidualetik taldekora eta taldetik norbanakora. Kategorien sistema eraikitzeko, bi bide jarraitu dira: deduktiboa eta induktiboa. Bide deduktiboan teoria arakatzetik (Ruiz Olabuenaga eta Ispizua, 1989), informazioa biltzeko tresnetatik (Rodríguez, Gil, eta García, 1996) edo teoriatik jasotako taxonomia-taldeetatik ere (Colás eta Buendía, 1998) etor daitezke kategoriak. Prozesu induktiboan, gertakarien inferentzia-zuzena eginez abiatu da sare kontzeptualen eraikuntza.

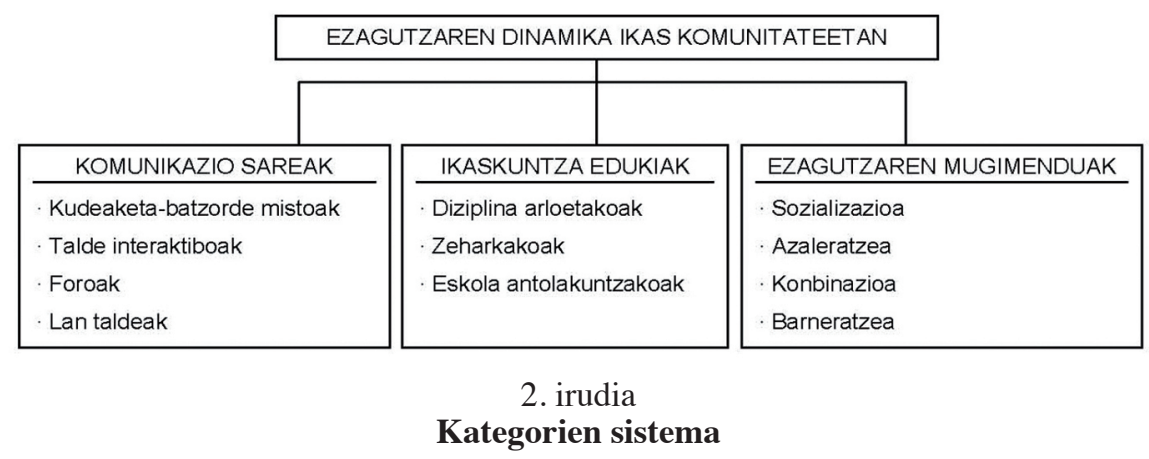

Kategorien sistemako lehenengo eta hirugarrengo multzoak, bide deduktiboan, bibliografian aurkitu diren ideia nagusietatik eta hastapeneko kontzeptu-eremutik eratorri dira. Bigarrena, induktiboagoa, lehenengo eremua hedatuz, landa-lanean bildutako informazioa irakurri ahala sortu da. Praktika induktiboan eta deduktiboan, zehaztapen gehiagorekin egindako analisi batean, kategorien inguruan multzokatu dira elementuak, kontzeptu-eremua berreraikitzeko sistema elaboratuz. Adierazle bakunak identifikatzeko nahiz kategoriei izena emateko, inferentzia baxuko deskriptoreak erabili dira, hau da, analizatu den edukian agertutako adierazpen testualetako hitzak; antzekoak edo hurbilekoak. Inferentzia gutxiko deskriptoreak erabiltzeak berresgarritasuna eransten dio ikerketari (Guba, 1983; Lincoln eta Guba, 1985). Zenbat eta inferentzia gutxiago, orduan eta fidagarriagoak dira datuak (Angera, 1997). 


\section{EMAITZAK ETA INTERPRETAZIOA}

\section{Komunikazio-sareak eta ikaskuntza-arloak}

Lehenengo bi eremuak aztertuta, interakzio-sareen askotarikotasuna ikus daiteke; aldi berean, sare horietan agertzen diren ikaskuntza-edukien arloak ere identifikatzen dira (3. irudia). Informazio-emaileek behin eta berriz adierazi dute gogobetetasuna beren ikastetxeetan lortu dutenaren aurrean eta horretan elkarlanak izan duen garrantziaz, eta, hori ikusirik, berariaz analizatu dira ikaskuntza-egoeren alderdi soziopertsonalak.

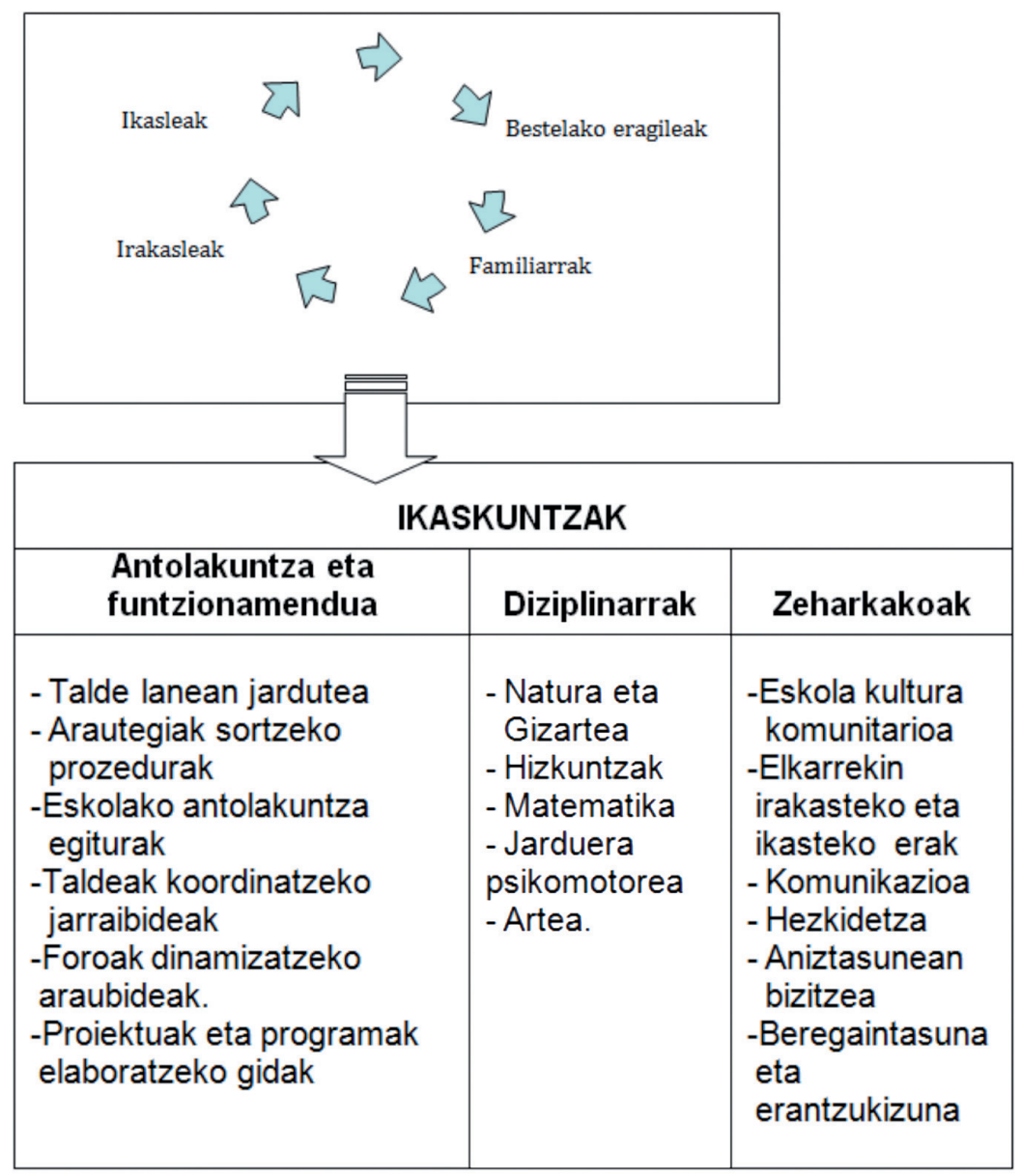

3. irudia

Ikaste-eremuak sare interaktiboetan 
Ikas Komunitateko partaideek - irakasleak, ikasleak, familiakoak, ikasle ohiak, borondatezko langileak edo aholkulariak izan - proiektuari buruz duten ikuspegia nabarmentzen dute, eta irmo agertzen dute berena eta komunitate osoa hartzen duena dela eraikuntza. Halaber, garrantzia ematen diete talde-lanarekin zerikusia duten alderdiei: entzutea, errespetatzea, bat etortzea, aniztasunean jardutea edota eztabaidan aritzea. Aldaketaren aurrean sortzen diren errezeloak gaindituta, irakasleak proiektuaren parte sentitzen hasten dira, hau da, sinetsi egiten dute horretan. Irakasleek aitortzen dute aldaketaren urratsik zailena izan dela komunitateko edozein kide ikasgeletan sartzeak eta kudeaketa-batzorde guztietan partaide izateak ematen zien beldurra gainditzea. Irekitasun hori da, hain zuzen, pertsonen arteko harreman berriak suspertzen dituen eta partaide-sentimendua indartzen duen giltzetako bat. Harremanen dinamika berri horrek ikasleei ere eragiten die, curriculumeko edukien ikaskuntza hobetzen baita. Ikastetxea komunitate gisa hartzeak lana elkartasunean egiteko era dakar, eta bakoitzak jakintza formala nahiz informala jasotzeko ipintzen duen jarrera baikorra azaltzen da.

Curriculumaren garapenari dagokionez, ikasle-taldeen konfigurazioaren izaera iragazkorrak beste era batera ikusarazten ditu irakaskuntza- eta ikaskuntza-prozesuak. Orain, eskola leku irekia da, irakasleekin batera beste eragileak sartu eta irtetea, ohikoa izanik, ontzat ematen duena. Ikasleen sendikoak borondatezko langile izan daitezke: ikasgelan esku hartzetik harago, konpromiso handiagoa hartzen dute komunitate osoarentzat modu aktiboan aritzeko.

Esan bezala, eguneroko esperientzia, ikasleez gainera, familiak eta borondatezko langileak ere kontuan hartuz gertatzen da, bi ikasgeletan, baita beste hezkuntza-jarduera diziplinarretan eta zeharkakoetan ere: hezkidetza-proiektuan, elkarbizitza-planean, irratian, edota baratzan. Sare elkarreragileak ikaskuntza-talde heterogeneo gisa eratzen dira, lana egiteko eta ikaskuntza zer den ulertzeko modu berriak erabiltzeko xedearekin. Antolamendu bateratzaile horrek hainbat lantalde sortzera behartzen ditu Ikas Komunitateak, hala nola foroak, batzorde mistoak edo talde interaktiboak. Sozializazio- eta interakzio-egoeretan oinarrizkoak diren baldintza eta giro onuragarrien sortzaile dira egitura horiek.

Antolakuntza-eredu konplexua eta demokratikoa izanik, zuzendaritzaorganoetatik harago hedatzen da kudeaketarako ikaskuntza. Esperientzian oinarritutako ikaskuntzaren eta berariazko prestakuntza-ekintza osagarrien bidez, familiakoek eta irakasleek koordinazio- eta plangintza-zereginak gauzatzen dituzte elkarrekin, lidergo instituzionalak eskatzen dituen erantzukizunak beren gain hartuz.

Talde barneko batasuna eta konfiantza funtsezko helburuetako bat da eskolaldiko etapa guztietako hezkuntza-jardunean. Ikaskuntza-edukien artean pertsonen nolakotasunak eta jarrerak sartzea dakar horrek. Komunikazio askea hasi eta mantentzea errazagoa da errespetua, jarrera irekia, mal- 
gutasuna, eskuzabaltasuna, konpromisoa, elkarren arteko konfiantza eta besteekiko begirune positiboa dagoenean; horregatik diote:

Nork beraren gabeziak onartzen ikasten dugu, ikasteko beharraren kontzientzia hartzen, besteena entzun eta geurea aintzat hartu dela ikusten, eta elkar baloratzen. (Zaldupe Ikas Komunitateko gurasoa)

Era esplizitu batean, curriculumeko ezagutza-arloetarako antolatzen diren talde interaktiboetan eta diziplinarteko egitasmoetan gauzatzen da zeharkako ikaskuntza-eduki hori; bai ikasgelako taldeetan, baita programa eta foro zabalagoetan ere. Pertsonen arteko gertuko harreman-giroan elkarri laguntzeko eta kooperatzeko kultura sortzen da, eta, kideak beti berak ez izan arren, muinak iraun egiten du. Irekia eta iragazkorra izanik ere, harreman dinamiko eta ezegonkorreko sistema honek, guztienak diren helburuek eutsita, mantendu egiten du goi-mailako orekako egitura.

Taldean jarduteari ematen zaion garrantziak eta kideetako bakoitzak eman dezakeenaz kontzientzia hartzeak erraztu egiten du ikasle eta irakasle etorri berriak ikaste- eta lan-taldeetan sartzea. Ekintza-planen garabidean beren gain hartzen duten konpromisoaren eta erantzukizun konpartituaren ondorioz, norbanakoaren atxikimendua haziz doa. Adibidez, atzerriko emakume etorri berriei harrera egiteko taldeetan ikus daiteke hori; berariazko laguntza-taldeak osatzen dira, lehendik eratuak dauden sareetara hurbiltzea errazteko.

\section{Ezagutzaren mugimenduak}

Hirugarren analisi-ildoan, Ikas Komunitateetako sare elkarreragileetako ezagutza-eraldaketak eta -mugimenduak bilatu nahi izan dira. Emaitzarik orokorrenean agertzen denez, esan daiteke lau prozesuei - sozializazioa, azaleratzea, konbinazioa eta barneratzea - lotutako ekintzak eta elementuak aurkitu direla (4. irudia). 


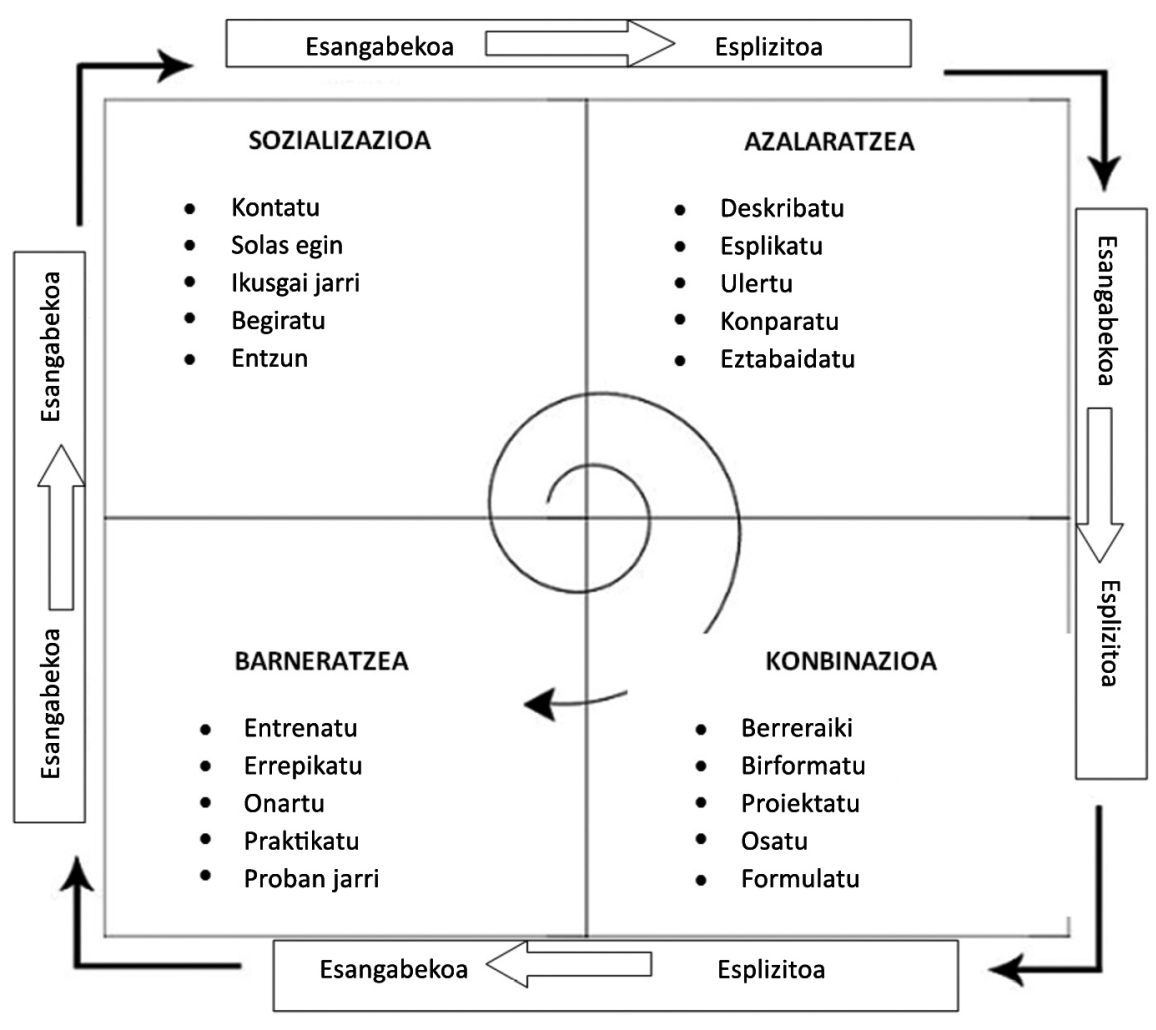

4. irudia

Ezagutzaren dinamika Ikas Komunitateetan

Ezagutzaren sozializazio-aldia ikastetxeko eguneroko bizitzan gertatzen da, berez sortutako egoeratan, ia bat-batean, nahiz aurretik planifikatutako egoera formaletan. Prestakuntza-ekintzetan, adierazpenen bidez, irudiak ikusiz edota inguruko lagunei begira egiten da ezagutzaren transmisioa, igortzea eta hartzea. Bestalde, eguneroko bizitzan - eskolako sarrerak eta irteerak, pasilloak, jaialdiak, atseden-tarteak, solasaldiak - , edozein unetan agertzen dira hastapeneko kontzeptuak, iruzkin, ideia zein amets moduan; kontzeptu horiek mintzagai izango dira gero erakundeko foroetan. Komunikazio-giro ireki eta naturaletan, erraztu egiten dira sozializazio-prozesuak. Gainera, elkarlanaren garrantzia dela eta, Ikas Komunitateetan denbora hartu ohi da pertsonen arteko harremanak sustatzeko, elkarrengana hurbiltzeko era berriak bultzatuz.

Ezagutza eraldatzearen bigarren prozesuak, hots, azaleratzeak, esplizitu egiteko ariketa motel bat eskatzen du. Helburua partaide guztiak gauza 
bera ulertzera iristea da, denen ezagutza azaleratzea hizkuntza bakarra eraikitzeko. Ikaskuntza-talde, mintegi, proiektu-talde, batzorde eta foro irekietako jardueretan mamitzen da. Azaleratzea eztabaida- eta argitze-saioetan gauzatzen da: hitzezko bitartekoak nahiz grafikoak erabilita gertaerak nahiz objektuak irudikatuz, lehendik ezagunak diren errealitateekiko azterketa konparatiboak eginez, antzekotasunak identifikatuz eta baita proposamenak argudiatuz ere.

«Bakoitza bere argudioak ahalik eta hobekien azaltzen ahalegintzen gara, gero, denen artean aukerarik egokiena zein den ikusteko» (Pedro M. Otaño Ikas Komunitateko irakaslea)

Guztiek ulertu eta onartzen dituzten hastapeneko definizioen bila elkarrekin hausnartzea dakar jarduera horrek. Ikas Komunitateetan, berebiziko garrantzia dauka barneko organoek batera parte hartzeak; ikasleak, familietakoak, irakasleak, borondatezko langileak, baita lekuko administrazioetako ordezkariak ere, bildu egin ohi dira ideiak argitzeko.

Esate baterako, Elkarbizitza Batzordearen bileran, ikasgela-talde bakoitzeko bi lagun (lau urtetik hamabira bitarteko neska-mutilak), familien ordezkariak, zuzendaritzakoak, eta jantokiaren irakasle arduraduna elkartzen gara, hamabostero. (Zaldupe Ikas Komunitateko Elkarbizitza Batzordeko Irakaslea)

Batzuen eta besteen hizkuntzak gerturatzeko ahalegina egitea eskatzen du aniztasun horrek, eta, horrenbestez, ikasgaitzat hartzen dute hori bera ere. Elkarbizitza-ordezkarien batzarra, zehazki, maiz egiten da, eta onartzen da hezkuntza-balio handiko esperientzia dela. Bileretan, egoerak deskribatu eta balioetsi egiten dira; behar izanez gero, irtenbideak ere azaltzen dizkiote elkarri. Ikasgeletako talde-tutoretza saioekin batera, Elkarbizitza Planaren Garabidean Batzordearen bilerak, kontzeptu berrien ezagutzaren eta jarreraren hezkuntzaz gainera, erakunde-funtzionamenduarekin zerikusia duten prozedurazko edukiak biltzen ditu bere baitan.

Pertsona helduen eta umeen arteko tarte kognitiboa dela eta, beharrezkoa izaten da gertakariak eta kontzeptuak adibide ezagunak emanez esplikatzea. Gainera, berbaldi guztiak jasotzeko, adi egotea eskatzen du, eta adierazpen hobeak egiten laguntzea, kide guztientzat ulergarriak diren mezu esanguratsuetara iristeko.

Hastapeneko ideiak berrikuntza-prozesu sortzaile batean konbinatuz lotzen eta ordenatzen diren heinean, ezagutza berria itxura hartzen da; informazioa argitu, esanguratsua dena hautatu eta proposamenak osatzeko garaia izaten da.

Bakoitzak dakarrena azaltzeko elkartzen gara, gertakari berriari begira dakarkiena bildu eta, gainera, iritzi edo proposamenak eztabaidatu, denon artean ados jartzeko. (Pedro M. Otaño Ikas Komunitateko irakaslea) 
Konbinazio-fasean, zirriborroetan irudikatzen dira ekimenak, aurrena; hurrengo elaborazioen ondorioz, espero diren esperientziak eta errealitate berriak aurreikusteko ereduak sortzen dira. Ikas Komunitateetan eguneroko praktiketan gauzatuz eta bilakatuz doazen ideien integrazio dialogikoan gertatzen da ezagutzaren konbinazioa. Etengabeko berrelikadura-dinamika horretan, ezinbestekoa da maiz elkarretaratzea eta biltzarraren kultura sustatzea.

Ezagutza bihurtzearen laugarren prozesuak - barneratzeak - aurreko beste hiruren ekarpenak biltzen ditu, eta, praktikaren bidez, norbanakoen jakintza finkatzen du. Ezagutza esplizitua isileko ezagutza bihurtzen da. Honela erantzun du irakasleetako batek lana elkarrekin egiteari ematen zaion garrantziari eta lehentasunari buruz galdetuta:

Guk ohituta gaudelako egiten dugu hau, ikasita daukagu; zuentzat, zerbait berria da. Horregatik, esplikazioak eskatzen dituzue. (Zaldupe Ikas Komunitateko Elkarbizitza Batzordeko irakaslea)

Denen artean eraikitako ezagutza barneratu ahal izateko, bakoitzak beretzat onartu behar ditu, aurrena, edukiak eta proiektuak, eta, era berean, ekintzetan konprometitu. Prozesu horietan, lagungarri dira entrenamendueta errefortzu-ariketak. Ikas Komunitateetan, ezagunak dira aldizkako ekitaldiak eta lan-jarduerak, eta, halakoak maiz izaten direnez, eragina dute prozeduren, kontzeptuen eta jarreren ikaskuntzan. Ikasgeletako eguneroko ekintza, batzordeen bilera, jaialdi, edo tailerrak bezalako jarraitutasuna duten egoera eta esperientzietan partaideek ezagutza barneratzen dute; betiere, «ikaskuntzaren gidari, aldian-aldian berriro hartzen diren ametsen inguruan» (Zaldupe Ikas Komunitateko Elkarbizitza Batzordeko irakaslea).

\section{ONDORIOAK}

Ikas Komunitateetan, etengabe gertatzen dira sozializazio-, azaleratze-, konbinazio- eta barneratze-mugimenduak. Ikastetxearen jarduera praktikoan, egitasmo berrietan nahiz beharrizan urgenteei erantzuna bilatzeko uneetan agertzen dira mugimendu horiek; dinamika horien bidez, taldean bat hartuta ipinitako helburuek gidatutako bilakaera bat mantentzen da. Sozializazio- eta azaleratze-prozesuak betiko ahozko komunikazioaren bitartez gauzatzen dira. Konbinazio-faseak, horretaz gainera, lan sistematikoa eskatzen du, elkartuko diren ezagutza-unitateak ordenatu, bateratu, sintetizatu eta erregistratzeko. Barneratzea eguneroko jardueraren ondorioa da, etengabe eta luzaroan ezagutza nork bere egitearen emaitza.

Ikasleei aurkezten zaizkien eduki multzoak aurrez emana datorren curriculum ofizialetik harago doaz. Ikasleek, elkarbizitzaren antolaketan eta 
garapenean duten lekua eta garrantzia dela eta, norbanakoaz gaindikoak diren erantzukizunak onartzen dituzte, eta diziplina-arloetatik harago hedatzen dira beren esperientzia-eremuak. Ikasleen familietakoei nahiz borondatezko langileei, berriz, diziplinetako edukiez eta didaktikako ezagutzaz jabetzea dakarkie ikasgeletako irakaskuntza- eta ikaskuntza-egoeratan parte hartzeak. Horrek guztiak askotariko edukien sistema bat sorrarazten $\mathrm{du}$, norabide anitzeko joan-etorriz osatua.

Ikas Komunitateetan, ezagutza eraldatzeko dinamikak mugiarazteko baldintza egokiak biltzen dira. Ikasleek, haurren familietakoek, irakasleek, borondatezko langileek eta beste laguntzaileek aho batez baieztatzen dute erabakiak elkarrekin hartzea eta lankidetzan aritzea direla erakunde-egitasmoari eusten dioten oinarririk garrantzitsuenak. Galga handiko helburuak onartuta daudenean, partaideak estamentu batekoak edo bestekoak izan, barneko gatazkak gutxitu egiten dira taldeetako interakzio kooperatiboan, eta, aldiz, kideen arteko erakarpen-loturak eratzen. Pertsonen arteko harremanak sendotu daitezen, berebizikoa da hizkuntza bateratu batera iristea. Lantaldeak antolatuz, komunitatearen talde-jakintza sortzen da, egitasmo integratzaileetan edo zeharkako prozesuetan. Taldearen gaitasuna -komunikazioan eta elkarlan eraginkorrean oinarritua - garatzeko, beharrezkoa da hainbat zereginetan elkarrekin aritzea eta esperientzia bidezko taldeikaskuntza abian jartzea.

Ikas Komunitateek, sistema irekiak izanik, inguruarekiko hartzaile diren eta agente anitzen parte hartzea sustatzen duten erakunde gisa funtzionatzen dute. Komunitateetan lan egiteak eraldaketa dakar parte-hartzaileentzat, eta kultura berri bat barneratzea eskatzen du. Sistema irekiak izanik, ikastetxeetako dinamiken analisien aurrean, batetik, galdetu liteke komunitatetik bere inguru hurbilera doazen zehar-ikaskuntzen transferentzien irispenaz eta nolakotasunaz, eta, bestalde, azter liteke zer ekarpenek duten eragina eskola-komunitatetik herrirako gizarte-eraldaketan.

Barneko ezagutzaren dinamikari dagokionez, enpresetako praktikakomunitateekin alderatuz, lan- eta ikasketa-taldeen heterogeneotasunarekiko interesa azpimarra daiteke. Aldez aurretik, logikoa litzateke pentsatzea pertsonen antzekotasunak eta hurbiltasun kognitiboak ikaskuntza kooperatiboaren errendimendua erraztu eta gehitu egiten duela. Jarduerak modu zehatzagoan deskribatzeko talde heterogeneoetan helduek duten zereginei buruzko elkarrizketa eta analisi sakonagoa egiteak, ordea, badirudi hobeto azaldu dezakeela zein garrantzitsua den ikasleek eta helduek batera parte hartzea foro eta batzordeetan.

Eskola bati funtsezko aldaketak dakarzkio Ikas Komunitate bihurtzeak, bai funtzionamenduari dagokionez, bai eskolaren zentzuaren eta izatearen inguruan. Sistema berrira egokitzeak nahasmena sortzen du Lehen Hezkuntzako azken urteetako ikasleengan. Halakoetan, beren ibilbide akademikoko eragozpenei aurrea hartze aldera (baldin eta halakorik suertatzen bada), gomendatzen da berariazko neurriak hartzea. Ondorioz, oro har, 
egokia litzateke ikertzea nola bizi duten ikasleek Ikas Komunitate izateko eraldaketa-prozesua ere.

\begin{abstract}
The experiments carried out in the Learning Communities of the Basque Autonomous Community reveal a variety of practices that permit fostering the creation of training and learning processes based on shared action. By conducting a qualitative study, we aim to describe the knowledge dynamics in the Learning Communities. Based on the direct observation of the realities and actions that take place every day in schools, the analyses attempt to interpret the knowledge building processes from the point of view of the practice communities in the organisations that learn. The results can be classified into two broad groups: learning objects and communicative networks; and the transfer and conversion of knowledge between individual and collective states. In the conclusions, it is exposed how the studied knowledge dynamics happens in the Practice Community. In addition, it is explained the implications these movements of knowledge transformations have upon the learning and teaching methodology.
\end{abstract}

Keywords: cooperative learning, learning communities, communities of practice, knowledge conversion, primary school.

Las experiencias que se han venido desarrollando en las Comunidades de Aprendizaje de la Comunidad Autónoma Vasca ofrecen una buena muestra de las diversas prácticas que promueven la cooperación e impulsan el aprendizaje. A través de este análisis cualitativo se describe, desde el paradigma de las comunidades de prácticas de las organizaciones, la dinámica de conocimiento de las Comunidades de Aprendizaje. En el análisis se han interpretado los procesos de construcción del conocimiento, partiendo para ello de la observación de sucesos y acciones cotidianas en los centros educativos. Los resultados se distribuyen en dos ámbitos: en primer lugar, las redes de comunicación y los contenidos de aprendizaje y, en segundo lugar, los movimientos de transformación del conocimiento y de los procesos individuales a colectivos.

Palabras clave: Comunidades de Aprendizaje, aprendizaje cooperativo, transformación del conocimiento. 
Les expériences acquises dans les Communautés d'Apprentissage de la Communauté Autonome Basque montrent la variété de pratiques qui permettent et favorisent la création d'actions de formation et d'apprentissage basées sur l'action partagée. À travers une étude qualitative, l'objectif consiste à décrire la dynamique de la connaissance dans les Communautés d'Apprentissage. En partant de l'observation relative à la présence des réalités et actions quotidiennes des Centres éducatifs, les analyses essaient d'interpréter les processus de construction de la connaissance depuis le paradigme des communautés de pratiques des organisations apprenantes. Les résultats se regroupent autour de deux axes: premièrement, les objets d'apprentissage et les réseaux de communication et, deuxièmement, les mouvements et processus de conversion des connaissances entre des stades individuels et collectifs. La conclusion offre un résumé des dynamiques de connaissances engendrées par les pratiques communautaires dans les communautés d'apprentissage. De plus, l'implication de ces mouvements de restructuration des connaissances dans la méthodologie d'enseignement et d'apprentissage est mise en évidence.

Mots clé: apprentissage coopératif, communautés d'apprentissage, conversion des connaissances, l'enseignement primaire.

\section{REFERENCIAS}

Aguado Iribarren, L. (2010). Familia ereduak gaurko eskolan. Tantak, 22 (1), 127-148.

Angera, M. T. (1997). Metodología de la observación en las ciencias humanas. Madril: Cátedra.

Al-adaileh, R.M., Dahou, K. eta Hacini, I. (2012). The impact of knowledge conversion processes on implementing a learning organization strategy. The Learning Organization, 19 (6), 482-496.

Barragán, D. F. (2015). Las comunidades de práctica (CP): hacia una configuración hermenéutica. Francisccanum, 163 (57), 155-176.

Barrio de la Fuente, J. L. (2005). La transformación educativa y social en las Comunidades de Aprendizaje. Teoría Educación Universidad de Salamanca, 17, 129-156.

Colás, M. P. eta Buendia, L. (1998). Investigación educativa. Sevilla: Alfar.

Duque, E., De Mello, R. eta Gabassa, V. (2009). Aprendizaje dialógico. Base teórica de las Comunidades de Aprendizaje. Aula de innovación educativa, 187, $37-41$.

Elboj, C., Puigdellívoll, I., Soler, M. eta Valls, R. (2002). Comunidades de Aprendizaje. Transformar la educación (6. ed.). Bartzelona: Grao.

Fernández, I. eta Leidner, D. (2008). Knowledge Management: An Evolutionary View. London: M.E. Shape. 
Ferrer Esteban, G. (2005). Hacia la excelencia educativa en las Comunidades de Aprendizaje: participación, interactividad y aprendizaje. Educar, 35, 61-70.

Flecha, R. eta Larena, R. (2008). Comunidades de Aprendizaje. Sevilla: Fundación ECOEM.

González Rey, F. L. (2000). Investigación cualitativa en psicología: rumbos y desafios. México: International Thomson editores.

Guba, E. G. (1989). Criterios de credibilidad en la investigación naturalista. In Pérez, A. eta Gimeno, J. (Edk.). La enseñanza: su teoría y su práctica. Madril: Akal.

Hong, J. eta Kuo, C. (1999). Knowledge management in the learning organization. The Leadership \& Organization Development Journal, 20(4), 207-215.

Hord, S. M. (1996). School professional staff as Learning community questionnaire. Austin, TX: Southwest Educational Development Laboratory.

Jaussi, M. L. (Koor.) (2003). Comunidades de Aprendizaje en Euskadi: una respuesta educativa en la sociedad de la información para todos y todas. Vitoria-Gasteiz: Eusko Jaurlaritzaren Argitalpen Zerbitzu Nagusia.

Jaussi, M. L. (2008). El aprendizaje dialógico, base de transformaciones educativas. Aula de infantil, 44, 31-34.

Lincoln, Y. eta Guba, E. G. (1985). Naturalistic inquiry. Beverly Hills: SAGE publications.

Lundvall, B. eta Johnson, B. (1994). The learning economy. Journal of Industrial Studies, 1 (2), 23-42.

Mugertza, K. (2005). El papel de la Administración en las Comunidades de Aprendizaje (la visión de la Administración vasca). Educar, 35, 93-99.

Nonaka, I. (1994). A dynamic theory of organizational knowledge creation. Organization Science, 5(1), 14-37.

Nonaka, I. eta Takeuchi, H. (1995). The Knowledge Creating Company. New York: Oxford University Press.

Nonaka, I., Toyama, R. eta Konno, N. (2000). SECI, Ba and leadership: a unified model of dynamic knowledge creation. Long Range Planning, 33(1), 5-34.

Padrós, M., Duque, E. eta Molina, S. (2011). Aportaciones de la investigación europea Includ-ed para la reducción del abandono escolar prematuro. Avances en Supervisión Educativa. Revista de la Asociación de Inspectores de Educación de España, 14, 1-17.

Resnick, L.B. (1993). Shared Cognition Thinking as Social Practice. In Resnick L.B., J. Levine, eta S.D. Bernard (Edk), Perspective on Socially Shared Cognition. Washington D.C.: APA.

Rodríguez, G.; Gil, J. eta García, E, (1996). Metodología de la investigación cualitativa. Málaga: Algibel.

Ruiz Olabuenaga, J. I. eta Ispizua, M. A. (1989). La descodificación de la vida cotidiana. Métodos de la investigación cualitativa. Bilbao: Universidad de Deusto.

Santiago, K., Lukas, J.F., Arrieta, E., Joaristi, L., eta Lizasoain, L. (2012). VitoriaGasteizko ikastetxetako guraso elkarteen zereginari buruzko azterlana. Tantak, 24 (1), 2012, 37-60.

Tomassini, M. (2000). Dinámica del conocimiento, comunidades de prácticas: perspectivas emergentes para la formación. Formación Profesional Revista Europea, 19, 43-53. 
Tseng, S. (2010). The correlation between organizational culture and knowledge conversion on corporate performance. Journal of Knowledge Management, $14(2), 269-284$.

Vigotsky, L. (1978). El desarrollo de los procesos psicológicos superiores. Bartzelona: Crítica.

Voulalas, Z.D. eta Sharpe, F.G. (2005). Creating schools as learning communities: obstacles and processes. Journal of Educational Administration, 43(2), 187-208.

Wenger, E. (1998). Communities of Practice: Learning, Meaning and Identity. Cambridge: Cambridge University Press.

Zalazar, R.J.D. (2011). Introducción a la Administración: Paradigmas de las Organizaciones. Edición digital: eumed.net. http://www .eumed.net/librosgratis/2011e/1090/ 2014ko martxoaren 27an kontsultatua.

Ziluaga, F. eta Iturbe, X. (2011). Personas mayores voluntarias en aulas de 5 años. Aula de infantil, 59, 38-41. 